\title{
Authoritarianism and Good Governance: An Annotated Bibliography:
}

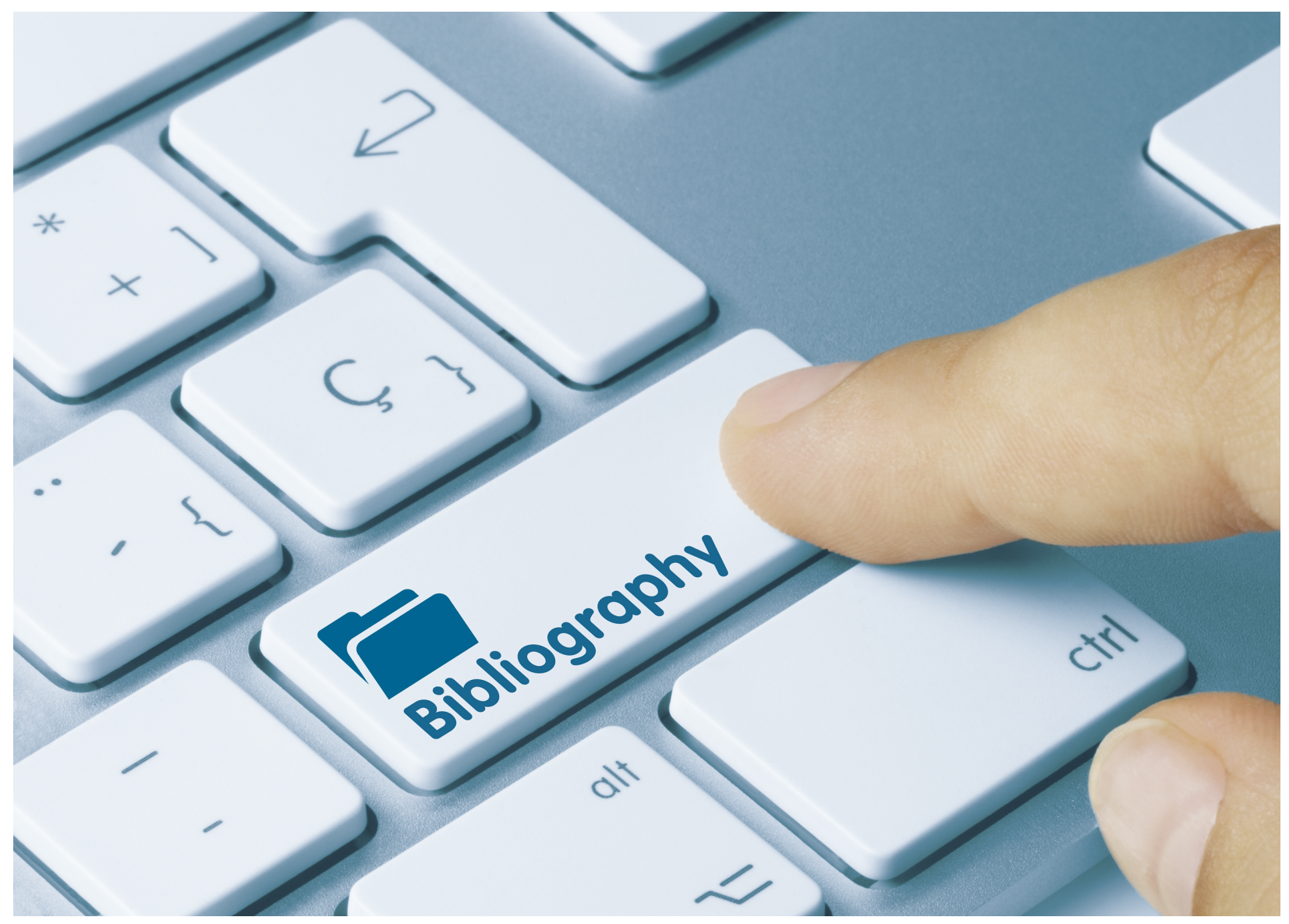

Fahmida Zaman and Sumeyra Yildirim

Department of Political Science \& International Relations

University of Delaware

Symposium on Authoritarianism and Good Governance

Muqtedar Khan (Ed.)

International Institute of Islamic Thought | February 2021

DOI: http://doi.org/10.47816/02.001.28 


\section{Adetula, V. AO. (2011). Measuring democracy and good governance in Africa: A critique of assumption and methods. Kwandiwe Kondlo, Chinenyengozi Ejiogu (eds). Africa in focus: Governance in the 21st century. Human Science Research Council.}

In this chapter, the author discusses the limits of liberal democracy along with the assumptions and methods that have been used to measure democracy and good governance in Africa by international donors and scholars. The author argues that many of the findings and conclusions in the donor-funded assessment reports on democracy and good governance in Africa are concerned essentially with regime type rather than the nature of the state and its relationship to the processes and outcomes of democratization. The article also highlights that most of the reports on the topic produced by international donors ignore the structural contradictions as a multifaceted constraint that prevent actualization of democracy in Africa.

\section{Bardhan, P. (2002). Decentralization of Governance and Development. Journal of Economic Perspectives, 16 (4), 185-205. https://doi.org/10.1257/089533002320951037}

In the economic policies of countries such as China and India as well as small countries in Latin America, Africa, and Asia, decentralization had been at the center stage. Decentralized governments were credited for industrial growth so much so that the World Bank and others embraced it as one of the major governance reform agenda. However, Pravab Bardhan argues that the literature on decentralization needs to go beyond the fiscal federalism literature. This is because the institutional context, hence the structure of incentives and organization, in developing and transition economies are quite different from the institutional context of industrial economies. For 
decentralization to work in developing and transition economies, there needs to be significant change in the existing structures of power within communities and to improve opportunities for participation of the disenfranchised in the political process.

Bellin, E. (2004). The robustness of authoritarianism in the Middle East: Exceptionalism in comparative perspective. Comparative Politics, 139-157.

Why have the Middle East and North Africa remained so singularly resistant to democratization? In answering this question, some argue that the Middle East and North Africa lack the prerequisites of democratization-the lack of a strong civil society, a market-driven economy, adequate income and literacy levels, democratic neighbors, and democratic culture explains the region's failure to democratize. Bellin contrasts these propositions and argues that the Middle Eastern exceptionalism does not lie in the absence of prerequisites of democracy. Rather, what distinguishes this region from others with regards to democratization efforts are a) access to abundant rent and subsidies that cover much of the cost of these overdeveloped coercive apparatuses and b) multiple western security concerns in the region guaranteeing continuous international support to authoritarian regimes in the Middle East and North Africa even after the cold war. These factors reinforce the coercive apparatus' capacity and prevent democratic reform.

Besley, T. (2006). Principled agents?: The political economy of good government. Oxford University Press. 
What is the role of government in the economy? One set of scholars argue that government is the force for public good that should regulate market, distribute resources, and should work towards improving the lives of its citizens. Another set of scholars argue that government is an agent driven by private interest, susceptible to those with the power to influence its decisions and failing to incentivize its officials to act for the greater public good. In this book, the author utilizes the Publius approach that acknowledges a middle ground. Timothy Besley discusses the institutional preconditions of effective governance and argues that it is not just about designing an appropriate institutional framework but also about understanding the way incentives work and the process by which the political class is selected.

\section{Bloom, P. (2016). Authoritarian Capitalism in the Age of Globalization. Cheltenham: Edward Elgar Press.}

In this book, Peter Bloom explores the rise of authoritarian capitalism in the age of globalization. He questions the possibility of breaking free from the results of authoritarian capitalism in the twenty-first century. Bloom argues that political authoritarianism is replacing liberal and social democracy. He points out capitalism's disciplining power through authoritarian nationalism, marketization, authoritarian modernization, authoritarian freedom, and authoritarian good governance. He challenges the conventional argument that capitalist prosperity can only be achieved through promotion of democracy by addressing the interplay between political authoritarianism and capitalism. He defines this process as "the tyranny of neoliberal democracy." This is a very engaging critical inquiry in grasping the structural factors beyond authoritarian tendencies around the globe. 


\section{Brownlee, J. (2007). Authoritarianism in an Age of Democratization. Cambridge University Press.}

The academic literature inspired by the extraordinary enthusiasm for the third wave of democracy ignored the evidence that many authoritarian regimes remained in power. Addressing this puzzle of varying fates of authoritarian regimes in the third wave period, Jason Brownlee in his book asked why are some autocratic governments overthrown after introducing elections, whereas others hold elections yet maintain autocracy? Brownlee argues that institutional differences distinguish unstable authoritarian regimes from durable dictatorships in which the presence and strength of ruling parties is a determining factor. Ruling parties can offer the structure for collective agenda setting and dispute mediation that regulate elites' clashing preferences and ambitions. As a result, whether an autocratic regime can survive or fall is determined by the availability of "soft-liners," a section of moderates who can ally with the regime to create mass support. Thus, the emergence of structural opportunities for democratization necessitates the decline of ruling coalitions.

\section{Cooley, A. (2015). Authoritarianism Goes Global: Countering Democratic Norms. Journal of Democracy 26(3).}

This article demonstrates the transformation of authoritarianism and the rising influence of non-Western powers and norms over the past decade. It explains how authoritarians implement the novel apparatus as well as practices, institutions, and 
alternative values to their advantage against the liberal international order. Cooley argues that global political changes and systemic transformations resulted in alternative norms that challenge liberal democracy and prioritize state security, civilizational diversity, and traditional norms. The author demonstrates these changes via a special emphasis on nongovernmental organizations (NGOs).

\section{de Sales Marques, J. L., \& Meyer, T. (Eds.). (2018). Multiple Modernities and Good Governance (1st ed.). Routledge.}

In this edited volume, José Luís de Sales Marques and Thomas Meyer represent a detailed investigation of the concept of "Multiple Modernities." The book addresses principal concepts such as development, good governance, human security, dialogue, harmony and human dignity, globalization, plural modernity, and varieties of capitalism. Addressing negotiated universals, the chapters provide alternative approaches to the concept of "multiple modernities" which enable us to discover the commonalities and differences in different regions around the globe. This book opens up novel ways of understanding and asks bold questions such as: Whose modernity? This book is a must read to comprehend the possibility of good governance in a world of multiple modernities which is "available to all."

\section{Diamond, L. J., Plattner, M. F., \& Walker, C. (Eds.). (2016). Authoritarianism goes global: The challenge to democracy. Johns Hopkins University Press.}

Over the last decade, just as authoritarian countries such as China and Russia have found new ways of authoritarian governance, established democracies such as 
United States and India have experienced decline of democratic values and norms. In this period, authoritarianism has gone global because a) authoritarian countries have been more assertive and have shared authoritarian tactics and practices with each other and b) in doing so, they have challenged the liberal international political order and standing of liberal democracy. Edited by Larry Diamond, Marc F. Plattner, and Christopher Walker, a distinguished group of scholars come together in Authoritarianism goes global: The challenges to democracy to offer fresh insights on the issues of worldwide democratic decline. Thematically, the book focuses area of "soft-power" competition centering on the role of information/disinformation war, civil society, and democratic norms. The collection of essays in this volume advance our understanding of the emerging challenges to democracy by focusing on authoritarian resurgence and implications of the systemic shifts for international order.

\section{Donno, D. (2013). Elections and Democratization in Authoritarian Regimes. American Journal of Political Science, 57(3), 703-716.}

In this article, Donno addresses an interesting puzzle-when do elections in authoritarian regimes lead to democracy? The author argues that competitive authoritarian elections have a better chance of resulting in democracy when the incumbent regime is relatively weaker. However, this is contingent upon domestic and international pressure-when there is an oppositional electoral coalition that is a unified front and when international actors threaten to punish the regime for violation of electoral norms. Using a comprehensive dataset of elections in authoritarian regimes from 1990 s to 2007, Donno confirms these findings and argue that alternative 
explanations such as the differences across regime type, better electoral conduct, or ongoing process of liberalization are not supported by the evidence.

\section{Doornbos, M. (2001). "Good Governance": The Rise and Decline of a Policy Metaphor? The Journal of Development Studies, 37(6), 93-108.}

Doornbos traces the rise and fall of good governance as a policy metaphor in international aid context. He illustrates that the notion of 'good governance' as a political condition has been a prominent policy requirement for international aid since 1989 onward. As part of a series of interlocking policy criteria and initiatives, international donor agencies enacted good governance on donor recipient countries. The genealogy of good governance metaphor is that it was first presented as a key objective in donor development and foreign policy in its own right; then, some donors treated it as a selection criterion for aid recipient countries, while more broadly it appears to be evolving into a general figure of speech without too much practical consequence. Thus, Doornbos argues, the "leverage to induce good governance" has not worked out as envisaged because it was posed as political conditionalities and policy metaphor; as such, the good governance connotation has lost its appeal.

\section{Gandhi, J., \& Przeworski, A. (2007). Authoritarian Institutions and the Survival of Autocrats. Comparative Political Studies, 40(11), 1279-1301. https://doi.org/10.1177/0010414007305817}

Jennifer Gandhi and Adam Przeworski address the issues of autocratic resilience by asking-why do some autocrats survive for decades, and others fall soon after taking 
power? Gandhi and Przeworski argue that autocrats face two types of threats to their rule: internal challenges which come from the ruling elite and external threats that come from outsiders within society. In order to tackle internal challenges from within the ruling class, authoritarian rulers establish narrow institutions such as consultative councils, juntas, and political bureaus. However, the authors argue that in order to neutralize challenges from outsiders within society, authoritarian rulers utilize "nominally democratic institutions." Particularly, the authoritarian rulers seek support from partisan legislatures to solicit cooperation and to neutralize the threat of rebellion from forces within society thus investing these actors in the ruler's survival. The authors test this hypothesis by analyzing all authoritarian rulers in power from 1946-1996.

\section{Gilbert, L., Mohseni, P. (2011) Beyond Authoritarianism: The Conceptualization of Hybrid Regimes. St Comp Int Dev 46, 270-297.}

In this article, Leah Gilbert and Payam Mohseni examine hybrid regimes by portraying the tensions and obscure relationships of democracy and authoritarianism. Their configurative approach challenges the idea of regimes' linear continuum (from authoritarianism to democracy). Instead, they focus on the alternative multi-faceted arrangements viable for the construction of regime types. This examination provides a better understanding of hybrid regimes and their particularities. The article's configuration helps readers to think about hybrid regimes beyond the framework of authoritarianism.

Guriev, S., \& Treisman, D. (2020). The Popularity of Authoritarian Leaders: A Cross-National Investigation. World Politics, 72(4), 601-638. 
This article, investigating the Gallup World Poll's panel of countries in 20062016, argues that the factors for political approval of authoritarian leaders vary across different regime types. It focuses on the perceptions of the individuals about their authoritarian states. The authors illustrate the different degrees and styles of authoritarian rule across the globe and try to uncover the reasons for the various levels of approval by their citizens. To that aim, they deepen our understanding of these different levels of approval through a cross-national investigation of elements such as economic performance, public safety, and covert censorship. Comparing overt dictatorships to milder informational autocracies, they conclude that the greater the repression, the lower the chance of approval.

\section{Hadenius, A., \& Teorell, J. (2007). Pathways from Authoritarianism. Journal of Democracy, 18(1), 143-157.}

On the question of prospects for democratization, some theories such as modernization theory attribute socioeconomic development as the main criteria while others have identified culture and religion, natural resources, and diffusion effects as major factors. Axel Hadenius and Jan Teorell in this article pay attention to the institutional requisites for democracy. They ask whether certain authoritarian regimes are more likely to break down and, if so, are certain types more likely to democratize? Do the institutional attributes of the authoritarian regime affect a country's prospects for democratic transition? To answer these questions, the authors develop a new typology of authoritarian regimes covering 191 countries in the world from 1972 to 2003. They argue that different types of authoritarianism have different propensities for survival and for democratization. Hence an institutional attribute-nature of the 
authoritarian regime-should be considered in any discussion of democracy's preconditions.

\section{Hadiz, V. (2016). Islamic Populism in Indonesia and the Middle East. Cambridge: Cambridge University Press.}

This book compares the evolution of Islamic populism in Indonesia to the Middle East. From a critical materialist approach, Hadiz argues that we cannot grasp Islamic Politics in different geographies without a deeper understanding of power, material resources, and social-historical structures. Through detailed case studies across the Middle East and Southeast Asia, he offers an in-depth analysis of political change in the context of socio-economic transformations. The case studies also tackle broader theoretical questions and present an innovative, comparative framework to shed new light on the diverse trajectories of Islamic politics in the modern world. He highlights the importance of the evolution of Islamic doctrines and ideologies in the modern world.

\section{Hagmann, T., \& Reyntjens, F. (Eds.). (2016). Aid and authoritarianism in Africa: Development without democracy. Zed Books.}

This edited volume by Tobias Hagmann and Filip Reyntjens examines the intersection between the international aid industry and politics from a variety of perspectives with a particular focus on Africa. The contradictory natures of the claims of democracy and human rights promotion by major bilateral and international donors, such as USAID, DFID, the World Bank and the European Commission, are particularly scrutinized as the aid policies in the region has become ever more entangled with the survival of their authoritarian protégés. The book sheds lights on the political intricacies 
and moral dilemmas of development policies which are shaped in the interest of maintaining the status quo. The book encourages research on a) moving beyond donorspeak and opening the "black box" of aid; b) addressing the accountability gap, i.e., the absence of a feedback loop between African citizens and Western taxpayers; c) research on historical trajectories, and d) "autocratic modernities," i.e., the attempts by African political elites to "amalgamate authoritarian politics with (neo-)liberal discourses emphasizing efficiency, effectiveness and performance."

\section{Hatchard, J., Ndulo, M., \& Slinn, P. (2004). Comparative Constitutionalism and Good Governance in the Commonwealth: An Eastern and Southern African Perspective. Cambridge: Cambridge University Press.}

This book explores the constitution-making processes in the Commonwealth countries (Eastern and Southern) and addresses the legal issues in the process of capacity building to ensure good governance. First, the authors draw our attention to the importance of good governance for the economic and social development of a country. Then, through a comparative approach, they aim to find out solutions to the problems of constitutionalism and draw lessons to make legislatures effective. The book features chapters analyzing presidentialism and restraints upon executive power's access to the political system, the devolution of power to local communities, and constitutional control of the military.

Hill, J. (2016). Democratisation in the Maghreb. Edinburgh: Edinburgh University Press. 
Democratisation in the Maghreb is a comparative analysis of democratization processes and political development in Tunisia, Algeria, Morocco, and Mauritania. This book challenges but also extends Levitsky and Way's model for examining political transitions by contextualizing each country's different experiences. After providing a detailed picture of post and pre-Arab Spring landscape, Hill argues that even though all of the countries in the region had been affected, and even though they had shared similar demands under similar conditions, their individual protest movements have resulted in different outcomes. These different outcomes provided by the article may deepen our perspectives about political development, governance, and authoritarianism.

\section{Hooghe, M., \& Quintelier, E. (2014). Political participation in European countries: The effect of authoritarian rule, corruption, lack of good governance and economic downturn. Comparative European Politics, 12(2), 209-232.}

Hooghe and Quintelier examine why the political participation levels in Central and Eastern Europe remain significantly lower than in Western European countries. The authors introduce a distinction between institutionalized and non-institutionalized forms of participation by conducting a multilevel analysis on the full sample of the European Social Survey in the period 2002-2008. The analysis of the data suggests that historical legacy of authoritarian regimes in these countries is an insufficient explanatory variable. Instead, high levels of corruption and lack of good governance appear to have a stronger effect on political participation. As a result, democratic participation levels are subjected to levels of corruption, which should be investigated more in depth. 


\section{Ishiyama, J. (2019). Is Democracy Necessary for Good Governance? Social Science Quarterly, 100(6), 2188-2208.}

John Ishiyama sheds light on the fact that a natural relationship between democracy and governance is assumed. By conceptually distinguishing democracy from good governance, Ishiyama investigates which regime type is more conducive to good governance. Data from 115 countries from 1996 to 2011, he finds that a) there is no difference between one-party regimes and democracies in terms of promotion of rule of law or effective governance in developing countries and b) some types of semiauthoritarian one-party regimes are better at promoting rule of law and effective governance than other types of authoritarian regimes and democracies. Thus, challenging the extant literature, this article demonstrates that democracy does not appear to be necessary for good "enough" governance.

Kendall-Taylor, A., Frantz, E., Wright, J. (2020) The Digital Dictators: How Technology Strengthens Autocracy. Foreign Affairs.

Authoritarian policies and institutional arrangements have spread across different regions of the globe and the norms about what makes up a legitimate regime has shifted dramatically. Within this framework, this article focuses on the new apparatus of authoritarian regimes: technology. New technologies, including the Internet and the cell phone, are widely perceived as promising which can ease the ways in which individuals create new connections and build communities through information. However, the authors contend that this is not the case. They challenge this view by illustrating how rulers use novel methods for their very survival. According to the authors, artificial intelligence (AI) allows authoritarians to advance techniques of 
monitoring and tracking of opposition. These digital tools enable authoritarian regimes to control a wider net by using fewer resources. Moreover, they conclude, this digital control is normalized in people's minds so that their resistance capacity to the system diminishes.

Khan, H.A. (2015). The Idea of Good Governance and the Politics of the Global South: An Analysis of Its Effects (1st ed.). Routledge.

In The Idea of Good Governance and the Politics of the Global South, Haroon A. Khan argues that the lack of good governance is the main trait of failed states. Presenting the major objectives of good governance such as human development and bureaucratic capacity, Khan contends that without good governance, many developing countries may become failed states. He strengthens his argument by the findings from the case study on the garment factory tragedy in Bangladesh. In so doing, Khan directs our attention to the importance of bureaucratic capacity for achieving good governance and the effects of globalization. Focusing on good governance and its relationship with failed states, globalization, bureaucratic effectiveness, and human development, this book provides a causal explanation for the relation between good governance and failed states.

Lagerkvist, J. (2009). Chinese eyes on Africa: Authoritarian flexibility versus democratic governance. Journal of Contemporary African Studies, 27(2), 119-134.

This article asks and attempts to answer two important questions regarding the impact of China's aid to and trade with African states: a) does China's 'no-strings- 
attached' policy in Africa constitute a challenge to Western aid paradigms and b) is there an emerging state-sponsored Chinese model of 'effective governance,' guided by a southsouth vision of mutuality, equality, and reciprocity at work? The author argues that although there are problems, there is reason to be hopeful about China's relations with African states because China is unwilling to force its experience of 'a market economy with Chinese characteristics' upon other nations. Hence, African analysts argue that local context should determine the development models for their countries and region. However, China's Africa watchers are cautious not to project any false hopes into the bilateral relationship between China and African states.

\section{Lai, H. (2016). China's governance model: flexibility and durability of pragmatic authoritarianism. Routledge.}

In China's governance model: flexibility and durability of pragmatic authoritarianism, Hongyi Lai explores how China's political development model can generate an alternative governance model which he defines as "pragmatic authoritarianism." The author underlines "the ability of China's government to rapidly transform a once impoverished economy and to recover from numerous crises from 1978 to the present" and provides an investigation of changes in China's institutions dealing with critical crises since 1978. Assessing leadership succession, crisis management, social welfare, leadership succession, and intraparty and grass-roots democracy, he portrays a positive view about the durability of governance in China. He also provides predictions about the future direction of China's governance model. 


\section{Leftwich, A. (1993). Governance, Democracy and Development in the Third World. Third World Quarterly, 14(3), 605-624.}

The dominant narrative of Western aid policies and development industry assert that 'good governance' and democracy are not simply desirable but essential conditions for development in all societies. This narrative has also recently asserted that democracy is a necessary prior or parallel condition of development, not an outcome of it. This assertation, of course, challenges modernization theories that contend that socioeconomic development leads the way to democracy. Beginning in early 1990s, democratic good governance began to emerge not simply as the new technical answer to the difficult problems of development but also as an intimate part of the emerging politics of the New World Order. Leftwich, in 1993, argues that the celebration of a victorious world-wide democratic revolution is hopelessly premature and that an era of democratic reversal, not democratic consolidation, is impending.

\section{Levitsky, S., \& Way, L. A. (2002). Elections Without Democracy: The Rise of Competitive Authoritarianism. Journal of Democracy 13(2), 51-65.}

In this 2002 article, Steven Levitsky and Lucan A. Way explore the concept of competitive authoritarianism. Challenging conventional thought, they demonstrate the arenas of contestation and the potential for opposition within these non-democratic polities. The authors question the literature on hybrid political regimes and provide an alternative yet robust theoretical framework. They argue that the literature often treats these hybrid regimes as incomplete or transitional forms of democracy. However, the authors challenge this assumption and illustrate how different regimes across the globe have either remained hybrid or moved in an authoritarian direction. Within this 
framework, they demonstrate how authoritarian regimes utilize formal and democratic institutions as means of obtaining and exercising political authority. They also underline the democratizing bias within the literature. In this regard, they argue that one should "stop thinking of these cases in terms of transitions to democracy and to begin thinking about the specific types of regimes they actually are." This detailed examination of competitive authoritarianism contends that "different mixes of authoritarian and democratic features have distinct historical roots, and they may have different implications for economic performance, human rights, and the prospects for democracy."

\section{Levitsky, S., \& Way, L. (2005). International Linkage and Democratization. Journal of Democracy, 16(3), 20-34.}

Following the end of Cold War, countries followed different paths with regards to democratization as some countries fully democratized, others became hybrid regimes while some remained autocratic. Levitsky and Way argue that the divergent paths of these regimes were heavily influenced by the countries' relationship to the West-i.e., Western leverage (governments' vulnerability to external pressure) and linkage to the West (the density of a country's ties to the United States, the European Union, and Western-led multilateral institutions). The external democratizing pressure through diffusion, diplomatic or military pressure, multilateral political conditionality, democracy assistance programs, and the activities of transnational human rights and democracy networks, were more intense and sustained in some regions (Central Europe, the Americas) than in others (sub-Saharan Africa, the former Soviet Union). Although 
both leverage and linkage raised the cost of authoritarianism during the post-Cold War period, it is the linkage that had the stronger effect of democratization.

\section{Lipset, S. M. (1959a). Democracy and Working-Class Authoritarianism. American Sociological Review, 24(4), 482-501.}

In this 1959 article, Lipset argues that the working class, particularly in poorer countries with low level of education, more than other social classes is predisposed to authoritarian and extremist attitudes. This is due to their tendency to view politics in "simplistic and chiliastic" way, i.e. black and white, good vs. evil. Thus, other things being equal, working class population is more likely to be attracted to anti-democratic and extremist movements, many of which suggest easy and quick solutions to social problems.

\section{Lipset, S. M. (1959b). Some Social Requisites of Democracy: Economic Development and Political Legitimacy. American Political Science Review, 53(1), 69-105.}

In the article, Lipset begins the discussion by identifying methodological and conceptual differences among political philosophers and political sociologists with regards to understanding and studying democracy. In the process, Lipset offers a definition of democracy which has a condition of institutions (i.e., parties, a free press, and so forth) as well as political actors (i.e., ruling and opposition parties). The definition of democracy is followed by discussion of two principal complex characteristics of social systems-economic development (comprising industrialization, wealth, urbanization, and education) and political legitimacy (the degree to which 
institutions are valued for themselves and considered right and proper). Lipset argues that these are structural characteristics of a society which sustain a democratic political system.

Mawere, M. (2015). Democracy, Good Governance and Development in Africa. Langaa RPCIG.

Scholars and development practitioners tend to view Africa either as a region that is incapable of achieving good governance, democracy, and socio-economic development or are overoptimistic about its potentials. Both of these narratives, however, downplay Africa's diverse as well as complex problems and predicaments. This edited volume engages with numerous issues ranging from the problems, challenges, and prospects of democracy and good governance to possible frameworks for fostering sustainable development in Africa through interdisciplinary engagement. Scholars in this book are gathered from Africa and from different fields of study including social anthropology, philosophy, history, political science, education, international relations, culture and heritage studies, religious studies, law, along with media and communication studies. They aim to dissect and critically examine the matrix of Africa's multifaceted problems on governance, democracy, and development in an attempt to proffer enduring solutions to the continent's long-standing political and socio-economic dilemmas and setbacks.

McCarthy, S., \& Thompson, M. R. (2020). Governance and democracy in the Asia-Pacific: Political and civil society. Routledge. 
In this edited volume, a distinguished group of scholars come together in exploring the theoretical and empirical relationship between democracy and good governance in the Asia-Pacific region. They advance our understanding through country-specific observations (China, Singapore, Thailand, Cambodia, the Philippines, Myanmar, Fiji, and the Solomon Islands) and through theoretical investigations on the issues of governance, civil society, development, democratic norms, and the rule of law. Providing an in-depth analysis of the structural and current trajectories of polities in the Asia-Pacific, they reveal how the role of civil society, political elites, and governance deviated in different regime structures. This work is important to critically reconsider the good governance literature and locate it in illiberal contexts.

\section{Nanda, V. P. (2006). The "Good Governance" Concept Revisited. The ANNALS of the American Academy of Political and Social Science, 603(1), 269-283.}

Nanda, in this article, traces the different ways the International Monetary Fund, the United States, and the World Bank have defined and used the term 'good governance' as a political condition for their aid policies in Africa. He argues that despite

the lack of clarity about the concept, a reiteration of good governance has been helpful in identifying problem areas that hamper the success of development aid. He also argues that the concept can be used effectively only when the cultural context and history are understood and sensitively taken into account.

\footnotetext{
Ortmann, S., \& Thompson, M. R. (2020). China's 'Singapore model' and authoritarian learning. Routledge.
} 
In China's 'Singapore model' and authoritarian learning edited by Stephan Ortmann and Mark R. Thompson, the scholars offer a comprehensive historical analysis of the "Singapore Model" and its adaptation in China. This model was used by the CCP to modernize while preserving authoritarian characteristics. This book portrays how Singapore managed economic modernization without having substantial political liberation which challenged the expectations of modernization theory. The authors demonstrate how Singapore became a model of "authoritarian modernism" for China to be implemented in order to bolster the CCP's legitimacy. Offering a detailed analysis of the "Singapore Model" and China's obstacles in internalizing it, they challenge the idea that democracy is the best regime form able to guarantee the good governance. They pay special attention to the learning process and knowledge transfer in Chinese reformation through collaboration and bilateral cooperation. However, they argue that the Singapore model is in decline under Xi Jinping. They conclude that there is a loss of interest in the Singapore model "due to Xi Jinping's fundamental reorientation of Chinese policy away from 'calibrated political reforms' and the foreign policy which puts greater emphasis on the success of China's own developmental policies." This book broadens our horizon to reconsider the possibility and importance of alternative epistemic communities and advances our understanding of good governance.

\section{Owen, C. (2020). Participatory authoritarianism: From bureaucratic transformation to civic participation in Russia and China. Review of International Studies, 46(4), 415-434.}

In conventional political and policy narratives, it is assumed that authoritarian regimes seek to "disengage and depoliticize" its citizens. In addition, they respond with 
coercion or co-optation tactics when there is mass mobilization. However, the author argues that such tactics are no longer the go-to mechanism in authoritarian states. Instead, well-established authoritarian regimes, such as Russia and China, have an abundance of local, voluntary, participatory mechanisms through which citizens can engage with politics and policy debates. Hence, there is a new form of participatory authoritarianism, and a driving force of such changes has been the marketization of state bureaucracies. This development requires more attention from academics as it challenges the view that authoritarian regimes are exclusively elite-led programs. Instead, it suggests that authoritarian regimes can be deeply embedded at the local level and enjoy grassroots legitimation and support.

\section{Sarsar, S., Datta, R. (2020). Democracy in Crisis Around the World. Lexington Books.}

Edited by political scientists Saliba Sarsar and Rekha Datta from Monmouth University, the diverse set of essays in this book address how the rise of authoritarian regimes and populist leaders is threatening democratic values around the world. The chapters point to the emergence of populist leaders and erosion of the core principles of democratic values as well as the capabilities of democratic institutions. The book examines five key regions-sub-Saharan Africa, Eastern Europe, Western Europe, Latin America, and the Middle East and North Africa-as well as four major countries: India, China, Russia, and the U.S. The main argument of the book is that democracies across the globe are in crisis. Highlighting democratic trajectories of different countries, the book aims to uncover the future implications of authoritarian resurgence. Providing the 
current responses of governments to the COVID-19 pandemic, this book sheds light on the fate of democracy for the foreseeable future.

\section{Scheiring, G. (2020) The Retreat of Liberal Democracy: Authoritarian Capitalism and the Accumulative State in Hungary: Challenges to Democracy in the 21st Century. Springer International Publishing}

A new wave of autocratization has been at the center stage over the last decade. Hungary's lessons can be relevant across the globe to tackle the inner logic of the worldwide democratic decline. Built upon three years of empirical research, this mixedmethods empirical study is crucial to grasp why liberal democracy has retreated. Gabor Scheiring, a Marie Curie Fellow at Bocconi University and a former member of the Hungarian Parliament, explores how Hungary's international economic integration resulted in internal socio-economic disintegration. Scheiring introduces a theoretical framework to better understand the political-economic nature and stability of the post2010 Hungarian regime. According to Scheiring, Hungary's new hybrid authoritarian regime is best understood as a political response to the tensions of globalization. The rising nationalism among the working-class and the negative impacts of deindustrialization translated into the consolidation of illiberal hegemony. The author reveals the political economy of illiberalism in Hungary by explaining the dynamics of the Competition State.

\section{Svolik, M. W. (2012). The politics of authoritarian rule. Cambridge University Press.}


In The Politics of Authoritarian Rule, Milan Svolik asks "What drives politics in dictatorships?" He argues that authoritarian regimes face two fundamental conflicts: (1) Dictators face threats from the masses over whom they rule (the problem of authoritarian control) and (2) challenges dictators face from the elites with whom they rule (the problem of authoritarian power-sharing). Using the tools of game theory, he explains why some dictators, such as Saddam Hussein, establish personal autocracy and stay in power for decades; why leadership changes elsewhere are regular and institutionalized, as in contemporary China; why some dictatorships are ruled by soldiers, as Uganda was under Idi Amin; why many authoritarian regimes, such as PRIera Mexico, maintain regime-sanctioned political parties, and why a country's authoritarian past casts a long shadow over its prospects for democracy, as the unfolding events of the Arab Spring reveal. The author utilizes statistical analysis of comprehensive, original data on institutions, leaders, and ruling coalitions across all dictatorships from 1946 to 2008.

\section{Thompson, M. R. (2004). Pacific Asia after 'Asian values': Authoritarianism, democracy, and 'good governance.' Third World Quarterly, 25(6), 1079-1095.}

In the aftermath of 1997 Asian economic crisis, 'Asian values' which was once credited with the region's economic 'miracle' was replaced by globalized 'good governance' discourse. Although there was initial hope of a regional wave of democratization of the region that were swept by development dictators, authoritarian regimes flourished only few years later. In this article, the author makes four arguments: first, Pacific Asia began as an 'imagined community' of developmental dictatorships, which made authoritarian development the 'original position' against which democratic 
governance is judged; second, the demise of 'Asian values' did not pose a significant challenge to economically developed dictatorships in the region; third, middle classbased reformist movements calling for good governance have contributed to the destabilization of the region's new democracies, and fourth, the U.S.-led anti-terror coalition provided several authoritarian rulers in the region to weaken internal opposition but new democracies faced international pressure to combat terrorism that led to local protest.

\section{Teets, J. C. (2013). Let many civil societies bloom: The rise of consultative authoritarianism in China. The China Quarterly, 213, 19-38.}

Academic literature as well as democracy promotion project emphasize that the presence of autonomous civil society organization is a critical component of the democratization process. The conventional arguments also assume that autonomous civil society opposes authoritarianism. In this article, the author challenges this assumption and demonstrate a new model in which there is collaboration between fairly autonomous civil society and authoritarian regime in China. Naming this model "consultative authoritarianism," Teets argue that the decentralization of public welfare and the linkage of promotion to the delivery of these goods facilitated the local government-civil society collaboration in China. Hence, the "consultative authoritarianism" presents a paradoxical scenario in which there is simultaneous expansion of a fairly autonomous civil society as well as the development of indirect tools of state control.

\section{Author Bios}




\section{Annotated Bibliography F.Zaman and S. Yildirim}

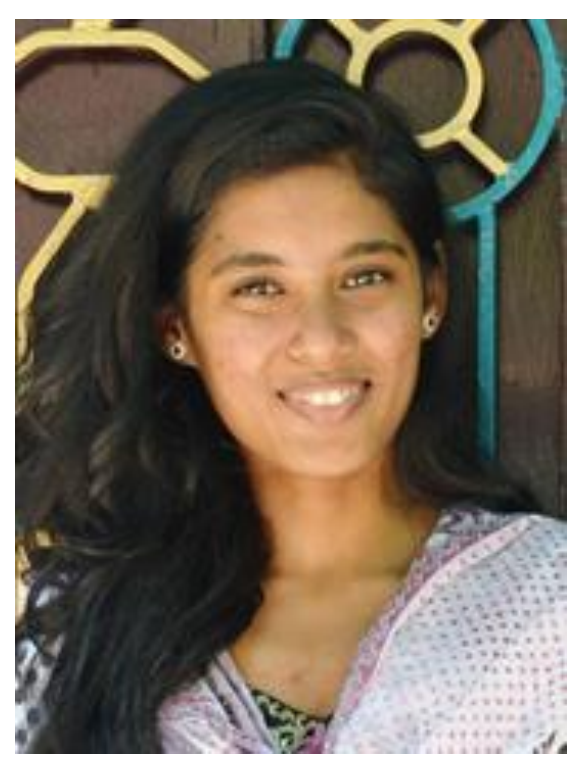

Fahmida Zaman is from Bangladesh. She has a BA from the Asian University for Women (AUW) in Bangladesh in Philosophy, Politics, and Economics (PPE) and studied for a year at St. Catherine University in Minnesota as a recipient of the undergraduate fellowship of the US State Departmentfunded Near East and South Asia Study Exchange program. She has an MA from Illinois State University in Political Science. She is one of the co-editors of Political Violence in South Asia, where her chapter focuses on representations of political violence in South Asian English fiction. Her writings on internet freedom, democratization, identity politics, and social movements in Bangladesh have appeared in the Journal of African and Asian Studies, Journal of South Asia as well as in the Daily Star. In the summer of 2020 she was a researcher at the Wilson Center.

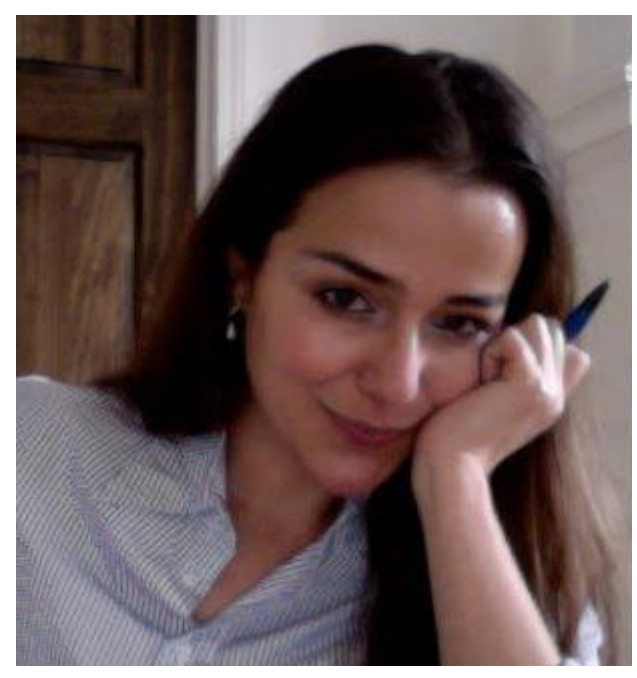

Sumeyra Yildirim is a doctoral candidate in the department of political science and international relations at the University of Delaware. She is a Fulbright Scholar. She holds an MA (2012) in political science and international relations from the University of Delaware. Her research interests include Islamophobia, identity, religion, fashion theory, and critical theory. In her dissertation, she seeks to demonstrate the myths linked to Islamophobia and the role of fashion in normalizing and challenging dominant discourses. She worked as a teaching assistant at the department of political science and taught courses at the English Language Institute at the University of Delaware. Yildirim has also worked with 
Institute for Global Studies (IGS) at the University of Delaware, assisting international programs funded by the U.S. Department of State. 